\title{
Effect of the Addition of Biochar and Coffee Grounds on the Biological Properties and Ecotoxicity of Composts
}

\author{
Michał Kopeć ${ }^{1}$ - Agnieszka Baran ${ }^{1}$ Monika Mierzwa-Hersztek ${ }^{1}$. \\ Krzysztof Gondek $^{1} \cdot$ Maria Jolanta Chmiel $^{2}$
}

Received: 26 September 2016 / Accepted: 25 March 2017 / Published online: 30 March 2017

(c) The Author(s) 2017. This article is an open access publication

\begin{abstract}
Propose The aim of this study was to investigate the effect of the composting process, conducted with the addition of various substrates, on the biological and ecotoxic properties of composts.

Methods Composts were prepared on the basis of plant material amended with biochar, sewage sludge, coffee grounds, or yeast effluent. The composting process was carried out for 140 days. The biological activity of mixtures was determined in the process, while microorganism abundance and ecotoxicity, in the final product.

Results The addition of biochar had no significant effect on the rate of the composting process measured by temperature; however, biochar-amended treatments showed a smaller loss of dry matter and higher C:N ratio. Compared to the control, reduced biological activity measured by the germination capacity of seeds was identified in treatments with maize straw composts and composts enriched with
\end{abstract}

Agnieszka Baran

Agnieszka.Baran@ur.krakow.pl

Michał Kopeć

m.kopec@ur.krakow.pl

Monika Mierzwa-Hersztek

m.mierzwa6@gmail.com

Krzysztof Gondek

k.gondek@ur.krakow.pl

Maria Jolanta Chmiel

Maria.Chmiel@ur.krakow.pl

1 Department of Agricultural and Environmental Chemistry, University of Agriculture in Krakow, al. Mickiewicza 21, 31-120 Krakow, Poland

2 Department of Microbiology, University of Agriculture in Krakow, al. Mickiewicza 21, 31-120 Krakow, Poland coffee grounds and yeast effluent. The inhibitory effect on the germination capacity was alleviated in treatments with biochar. The addition of biochar to compost with sewage sludge decreased the abundance of Escherichia coli and Salmonella ssp. and increased the total number of bacteria and fungi. In the case of composts with coffee grounds, biochar had an opposite effect to that observed for composts with sewage sludge.

Conclusions Biochar to sewage sludge and coffee grounds reduced ecotoxicity of composts to test organisms: Vibrio fischeri, Sianpis alba, Triticum L. and Eisenia fetida.

Keywords Biochar - Coffee grounds - Compost · Biological activity $\cdot$ Microorganisms $\cdot$ Ecotoxicity Biotests

\section{Introduction}

It is assumed that composting and pyrolysis are environmentally-friendly technologies for reducing biodegradable waste stream, and its further recycling [1]. These processes allow to convert unstable organic waste (e.g. sewage sludge, tannery waste, solid municipal waste, or animal manure) into products with valuable agronomic properties. The results of numerous studies show that the application of both biochar and compost in the soil significantly increases the supply of nutrients, the organic matter content, and improves soil structure and its buffer abilities [2, 3]. Another advantage of biochar, distinguishing it from other organic materials, is a high content of stable carbon resistant to microbial decomposition in soil. Therefore, composting with biochar favours the formation of complex bonds of organic acids, and their greater stability [4]. Studies published in the last few years indicate that the addition 
of biochar to the composted biomass is very beneficial, as it reduces ammonia emissions and, in consequence, gives better properties of the final product [4-6]. There is also an evidence that composting carried out with the addition of biochar significantly improves aeration and moisture retention in the composted biomass, and thus stimulates the development and life processes of microorganisms [7]. Compost made with biochar is commonly defined as "biochar-compost" and it is more and more often used to improve the soil quality. Currently, there are three known methods of producing and using biochar-compost. The first method involves direct mixing of biochar with compost and application of the resulting mixture into the soil without additional incubation [8], the second method involves co-composting of biochar with other raw feedstock inputs before they are applied into the soil; the third method consists in the incubation of biochar with fresh compost for a certain period, directly before its introduction into the soil [6]. However, there is very little information about the influence of not readily biodegradable carbon fraction, present in biochar and coffee grounds. The fraction is considered the most stable and persistent form of carbon in organic matter, which could contribute to the storage of $\mathrm{C}$ in the soil and its effect on biological properties and ecotoxicity of composts.

Food waste in the form of coffee grounds can be a substitute of biochar. Coffee is one of the most popular agricultural products and the second most commonly marketed goods in the world. This in turn leads to the generation of significant quantities of food waste $[9,10]$. At present, it is usually disposed of to landfills as mixed municipal waste, making the storage criteria stricter due to its high stability and limited biodegradability. Despite many valuable substances contained in this material such as organic carbon [11], direct introduction of the material into the soil can be toxic to microorganisms and plants. The basis for this is the presence of different organic compounds in coffee grounds, such as: phenol, chlorogenic acid, hydroxycinnamic acid, quinic acid derivatives [12]. To our knowledge, most studies on coffee grounds is focused only on their chemical contaminants, while studies describing their biological and ecotoxicological properties remain incomplete.

Biological properties of substrates have a direct impact on the thermal parameters and chemical processes taking place during composting, but also on the processes in the soil after application of compost $[6,13]$. Microbial degradability of organic material depends not only on nutrients and their availability in the material, but also, to a large extent, on chemical and physical conditions of the environment. Proper selection of substrates provides opportunities for accelerating the composting process. This is due to the form of air-water relationships which affect the biological activity of the composted biomass. In environmental sciences, biological activity is considered as the intensity of life processes of organisms under given conditions, e.g. in soil, compost. This multi-directional aspect can be measured by: the degree of microorganisms' growth, respiration activity, enzymatic activity (especially of dehydrogenases and phosphatases), the intensity of ammonification, nitrification, amylolysis (starch decomposition) and biological nitrogen fixation, the degree of accumulation of biologically active substances (vitamins, a.indoleacetic acid, gibberellic acid, and other), and synthesised by microorganisms. Biological activity is regarded as a potential measure of environmental status. High biological activity should be reflected in low toxicity. Attempts to modify the biological activity of the compost are therefore entirely justified, since they translate into quantitative and qualitative parameters of the crop.

Given the diversity of the analysed mixtures and multidirectionality of microbiological changes during composting, a study was conducted with the aim to assess the effect of the composting process and the addition of substrates in it, on the selected biological properties and ecotoxicity of composts. These substrates contain persistent carbon, so the composting process is unusual. Studies of ecotoxic properties of composts were conducted bearing in mind their possible natural use or the need to dispose them in the absence of compliance with standards.

\section{Materials and Methods}

\section{Conditions and Scheme of the Experiment}

Waste was composted for 140 days; from mid-May to the end of September 2015. The process was carried out in $1.2 \times 1.0 \times 0.8 \mathrm{~m}$ bioreactors with perforated bottom to allow an active aeration. Laboratory bioreactors were sheltered against precipitation, but exposed to the outside temperature and sunlight. This ensured heat exchange between the composted material and the surrounding environment. The basic feedstock used in the composting process was shredded maize straw (29.3 kg D.M.) (Table 1). Biomass prepared in this way was amended with municipal sewage sludge; food waste (coffee grounds) and willow biochar (prepared by industrial method at $600^{\circ} \mathrm{C}$ ) or effluent formed during the production of yeast (industrial waste). The scheme of the experiment included six treatments: $\mathrm{M}-$ control-maize straw; M+MSS-maize straw + municipal sewage sludge; $\mathrm{M}+\mathrm{MSS}+\mathrm{BC}$-maize straw + municipal sewage sludge + willow biochar; $\mathrm{M}+\mathrm{CG}$-maize straw + coffee grounds; $\mathrm{M}+\mathrm{CG}+\mathrm{BC}-$ maize straw + coffee grounds + willow biochar; $\mathrm{M}+\mathrm{CG}+\mathrm{E}-$ maize straw + coffee grounds + yeast effluent. 
Table 1 Dry matter losses and selected characteristics of the obtained composts

\begin{tabular}{lllllll}
\hline Treatment & Residue $^{\mathrm{a}}(\%)$ & $\mathrm{Ash}\left(\mathrm{g} \mathrm{kg}^{-1}\right)$ & $\mathrm{EC}\left(\mathrm{m} \mathrm{s}^{-1}\right)$ & $\mathrm{pH}$ & C:N before & C:N after \\
\hline $\mathrm{M}$ & 36.0 & $188.9 \pm 9.4$ & $6.78 \pm 0.20$ & $7.89 \pm 0.20$ & $37.3 \pm 0.9$ & $12.6 \pm 0.2$ \\
$\mathrm{M}+\mathrm{MSS}$ & 39.7 & $272.6 \pm 10.3$ & $4.86 \pm 0.18$ & $7.96 \pm 0.18$ & $28.3 \pm 0.8$ & $10.3 \pm 0.2$ \\
$\mathrm{M}+\mathrm{MSS}+\mathrm{BC}$ & 43.7 & $263.7 \pm 8.8$ & $4.64 \pm 0.18$ & $7.60 \pm 0.21$ & $30.7 \pm 1.1$ & $13.5 \pm 0.3$ \\
$\mathrm{M}+\mathrm{CG}$ & 45.8 & $136.3 \pm 5.4$ & $2.78 \pm 0.08$ & $7.01 \pm 0.19$ & $27.9 \pm 1.2$ & $10.9 \pm 0.4$ \\
$\mathrm{M}+\mathrm{CG}+\mathrm{BC}$ & 52.3 & $125.1 \pm 4.9$ & $2.70 \pm 0.11$ & $7.33 \pm 0.12$ & $29.2 \pm 1.3$ & $12.2 \pm 0.3$ \\
$\mathrm{M}+\mathrm{CG}+\mathrm{E}$ & 57.3 & $161.8 \pm 5.7$ & $7.15 \pm 0.22$ & $6.65 \pm 0.24$ & $27.5 \pm 0.9$ & $11.8 \pm 0.3$ \\
\hline
\end{tabular}

$M$ control-maize straw, $M+M S S$ maize straw + municipal sewage sludge, $M+M S S+B C$ maize straw + municipal sewage sludge + willow biochar, $M+C G$ maize straw + coffee grounds, $M+C G+B C$ maize straw + coffee grounds + willow biochar, $M+C G+E$ maize straw + coffee grounds + yeast effluent

${ }^{a}$ Weight of substrates before compositing were adopted as $100 \%$
The amount of waste materials introduced into the composted maize biomass were limited not only due to their physical parameters, but also because of the humidity of the feedstock. The proportions of feedstocks used in individual treatments were, by weight of the dry matter: $\mathrm{M}+\mathrm{MSS}-1: 0.15 ; \quad \mathrm{M}+\mathrm{MSS}+\mathrm{BC}-1: 0.15: 0.1$; $\mathrm{M}+\mathrm{CG}-1: 0.89 ; \quad \mathrm{M}+\mathrm{CG}+\mathrm{BC}-1: 0.89: 0.1$; $\mathrm{M}+\mathrm{CG}+\mathrm{E}-1: 0.89: 0.07$. After mixing the materials, moisture of the mixture was equilibrated to $60 \%$ by weight. Aeration of the biomass was performed in cycles, six times a day; the air was flowing through the bioreactor in the amount of $15 \mathrm{dm}^{3} \mathrm{~min}^{-1}$ for $60 \mathrm{~min}$; the biomass was manually shifted every 10 days. In the course of the composting process, the outside temperature in the shadow and temperature of the composed biomass (at half height of the composted matter) were recorded every 30 min using DT-171 data logger. Material for analyses was collected every 20 days, immediately after mechanical mixing of the composted material. Biological activity was determined in materials by manometric method. Compost samples collected after 140 days were regarded as a mature compost, and other biological and chemical parameters, as well as ecotoxicity of compost were determined.

\section{Chemical and Physical Analyses}

In order to identify the properties of matter composted by aeration, dry materials were dried at $105^{\circ} \mathrm{C}$ for $12 \mathrm{~h}$ (Jindo et al. [5]) and analysed. The $\mathrm{pH}$ of materials (material:water $=1: 2.5$ ) was determined electrochemically using $\mathrm{pH}$ meter ( $\mathrm{pH}$-meter $\mathrm{CP}-505)$, electrical conductivity (material: water $=1: 2.5$ ) using conductivity meter (conductivity/oxygen meter CCO-501) (Meier et al. [32]), and the contents of total nitrogen and carbon were determined using elementary analyser (Vario EL Cube, Elementar Analysensysteme 2013).

\section{Biological Activity}

\section{Respiration Activity}

Respiration activity of the composted materials was determined by manometeric method, using Oxi-Top measuring apparatus, in accordance with ISO 14855-1:2005 [14] (Fig. 1). Samples used in the study had $100 \mathrm{~g}$ of fresh mass. In order to determine the amount of sample dry matter remaining after the process, it was dried at $105^{\circ} \mathrm{C}$ for $12 \mathrm{~h}$ [5].

The manometric measurement of respiration activity of the studied composts involved recording of pressure changes in closed containers in a continuous system (Fig. 1). Pressure changes are proportional to the amount of oxygen consumed by the sample as a result of respiration processes occurring in it [15]. Measuring time for respiration activity was 5 days ( 1 day to stabilise conditions and 4 days of actual measurements of respiration activity). Pressure changes were recorded automatically every $30 \mathrm{~min}$. The resulting equivalent quantities of $\mathrm{CO}_{2}$ were absorbed by $1 \mathrm{~mol} \mathrm{dm}^{-3} \mathrm{NaOH}$ present in the vessels. The system used for the measurement of respiration activity consisted of $2.5 \mathrm{dm}^{3}$ measuring bottles with accessories. For the time of determination, measuring bottles were put into a thermostatic cabinet, providing a constant temperature of $25.0^{\circ} \mathrm{C}$ $\left( \pm 0.1^{\circ} \mathrm{C}\right)$. Measurement data was sent to the controller through an infrared interface, and then, to the computer using Achat OC. Biological activity of composted material was converted into dry matter by the following formula:

$B A=\frac{M_{\mathrm{O}_{2}}}{R \cdot T} \cdot \frac{V_{f r}}{m_{B t}} \cdot|\Delta p|\left[\mathrm{mg} \mathrm{O}_{2}(\mathrm{~g} \mathrm{~h})^{-1}\right]$

where $\mathrm{BA}$-biological activity; $\mathrm{M}_{\mathrm{O}_{2}}$-molecular weight of oxygen $\left(31,998 \mathrm{mg} \mathrm{mol}^{-1}\right)$; $\mathrm{R}$ - universal gas constant [83.14 L hPa $\left.\left(\mathrm{K} \mathrm{mol}^{-1}\right)^{-1}\right]$, T-measurement temperature $(\mathrm{K}), \mathrm{mBt}$-dry mass weight in the composted material $(\mathrm{kg}) ;|\Delta \mathrm{p}|$ —pressure change $(\mathrm{hPa}), \mathrm{Vfr}$-free gas volume. 
Fig. 1 OxiTop ${ }^{\circledR}$ control measuring set for respiration activity

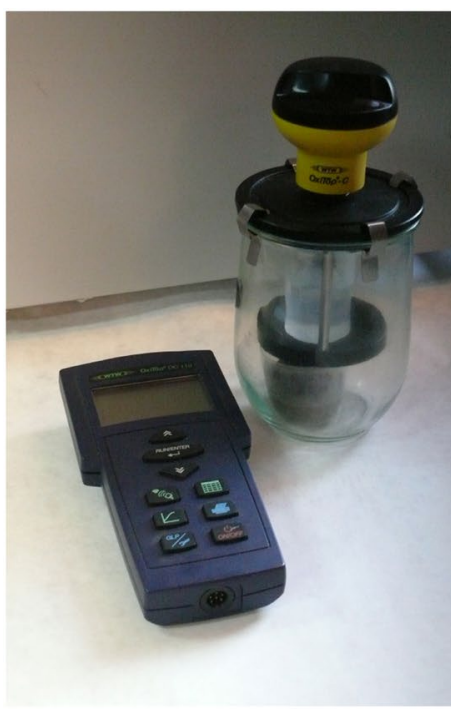

\section{Germination Energy Test}

The analysis of germination energy of spring wheat seeds of cultivar Struna in contact with the 1:10 extract of composts (compost : redistilled water) was carried out under conditions of a closed container with carbon dioxide removal and manometric measurement (Oxi-Top). The control object was vessel in which the germination energy test was conducted exclusively against redistilled water. The seed weight of $5 \mathrm{~g}$ was used in the analysis. The test was conducted for 3 days. The result of germination energy test was calculated using the formula (1), presented in the form of regression equation of oxygen consumption $36 \mathrm{~h}$ after addition of extract of composts, and expressed in $\mathrm{O}_{2}(\mathrm{~g} \mathrm{~h})^{-1}$.

\section{Microbiological Analysis of Composts}

Quantitative and qualitative analyses of microorganisms in composts were made by serial dilutions, using general and selective growth media. Results were reported as the number of colony forming units per $1 \mathrm{~g}$ D.M. of the sample $\left[\mathrm{jtk} \cdot \mathrm{g}^{-1}\right.$ ] [16]. The total number of bacteria and fungi and the abundance of Escherichia coli and Salmonella ssp. were determined.

\section{Ecotoxicity of Composts}

Phytotoxicity of composts was determined for two phases: solid and liquid (extracts), using three test organisms. Additionally, the zootoxicity test with Eisenia fetida was performed for the solid phase. 1:10 extracts of composts (compost:redistilled water) were tested for ecotoxicity to Vibrio fischeri, Sinapis alba and Triticum L. In the Microtox test with Vibrio fischeri, change in a light emission intensity, depending on the degree of the sample toxicity, was tested. The percentage of reduction of emitted light means a decreased metabolic rate of bacteria and is an indicator of the sample relative toxicity. The procedure of 81.9\% Screening Test [17] was used in the assessment of extracts' toxicity to $V$. fischeri. Measurement of the luminescence was carried out before and after 15 min incubation of the bacterial suspension with the studied sample and then, toxicity effect I (\%) was calculated according to the equation:

$\mathrm{IL}=[1-(\mathrm{B} / \mathrm{A})] \times 100 \%$

where IL-inhibition of luminescence (\%); B-intensity of luminescence of the studied sample; A-intensity of luminescence of the control sample $(1000 \mu \mathrm{l} 2 \% \mathrm{NaCl}$ with $150 \mu \mathrm{l}$ bacterial suspension).

Phytotoxicity of extracts to Sinapis alba and Triticum L was studied with Phytoteskit test. The studied parameter was inhibition of growth of plant roots in the obtained extracts. The test was conducted in accordance with the procedure recommended by the manufacturer in special test plates $(21 \times 15.5 \times 0.8 \mathrm{~cm})[18] .20 \mathrm{~cm}^{3}$ of the extract was slowly spread over the entire surface of the white filter paper in order to hydrate the filter paper completely. The test plates were covered by a black paper filter, and test seeds were sown at the rate of ten pieces per plate. The plates prepared in this way were incubated in a horizontal position at $25^{\circ} \mathrm{C}$ in darkness for $72 \mathrm{~h}$. Afterwards, the image was registered by digital camera and the root length was measured using "Image Tools" programme for image analyses. The percent inhibition of root growth (IR) for the plant were calculated with the formula:

$\mathrm{IR}=[(\mathrm{A}-\mathrm{B}) / \mathrm{A}] \times 100 \%$, 
where $\mathrm{A}$-is the mean root length in the control, and $\mathrm{B}$-is the mean root length in the test samples.

Zootoxicity of composts (solid phase) was determined in a test with Eisenia fetida earthworm. The test involved the determination of mortality of adults, 14 days after their placement in the studied composts. The test was conducted in $1 \mathrm{dm}^{3}$ plastic containers filled with $700 \mathrm{~cm}^{3}$ of composts. In each container, there were 10 E. fetida adults (with wellformed clitellum). Substrate moisture content was maintained at $50-60 \%$. The rate of earthworm mortality after 14 days was calculated as follows:

$\mathrm{M}=(\mathrm{A}-\mathrm{B} / \mathrm{A}) \times 100 \%$

where $\mathrm{M}-$ mortality rate; $\mathrm{A}-$ number of live earthworms, B-number of live earthworms in the studied sample.

\section{Analysis Quality Control and Statistical Analyses}

Chemical, biological and ecotoxicological determinations in all the analysed samples were performed in three replicates. The results of microbial determinations were reported as $\mathrm{CFU} \cdot \mathrm{g}^{-1}$ dry matter and the toxicity results were expressed as a percentage of the test reaction (PE\%). The accuracy of analyses was verified based on the certified reference materials and standard solutions: CRM IAEA/V-10 Hay (International Atomic Energy Agence), CRM-CD281-Rey Grass (Institute for Reference Materials and Measurements). The obtained data were compiled with the use of STATISTICA 12 (StatSoft Inc.). Variations in the properties were determined by calculating the standard deviation $( \pm \mathrm{SD})$.

\section{Results and Discussion}

\section{Selected Chemical and Physiochemical Properties of Composts}

The highest loss of dry matter $(64 \%$, Table 1$)$ was determined in the case of maize straw (M) composting. Dry matter loss was reduced in M+MSS and M+MSS + BC treatments amended with sewage sludge, which was due to, inter alia, its increased ash content. Biochar and coffee grounds are stable materials, less prone to biological decomposition and weight loss during the process. The accumulation of effects was observed after introducing yeast effluent into the composted matter: changes in the chemistry of the environment, reduced decomposition through narrowed diversity of microbiological decomposition, and reduced decomposition of stable carbon from coffee grounds.

In all treatments, an indirect indicator of compost stability-the $\mathrm{C}: \mathrm{N}$ ratio-decreased about 3 times in relation to its value determined before composting. After the composting process, the range of $\mathrm{C}: \mathrm{N}$ ratio was $10.3-13.5$, which can be regarded as the end of the process.

Apart from nutrients, the environmental conditions, including electrical conductivity and $\mathrm{pH}$, influence the development of bacteria and fungi [19]. The resulting composts had different values of electrical conductivity and $\mathrm{pH}$ (Table 1). Composts with the addition of coffee grounds, i.e. obtained from material leached from ions, had the lowest EC values. The highest electrical conductivity was found in $\mathrm{M}+\mathrm{CG}+\mathrm{E}$ treatment amended with yeast effluent and characterised by a large proportion of easily soluble ions. The addition of stable materials, such as biochar and coffee grounds could reduce the compost salinity. Due to the development of specific surface, these materials bound alkaline cations in composts. The study results revealed that coffee grounds acidified the composted biomass. The lowest $\mathrm{pH}$ value was determined in $\mathrm{M}+\mathrm{CG}+\mathrm{E}$ treatment, amended not only with coffee grounds, but also yeast effluent (Table 1).

\section{Changes in Temperature During Composting}

The outside temperature reflected the meteorological conditions in the months in which the composting process was conducted. In the control treatment $(\mathrm{M})$ and treatments amended with sewage sludge (M+MSS, M+MSS + BC), in the first 14 days, temperature of the composted matter increased to over $50^{\circ} \mathrm{C}$ and remained at a similar lever for 28 days, indicating intensive microbiological processes during that period (transition from thermofit phase). Based on the temperature it was stated that microbiological processes in these treatments rapidly ended after 28 days, and after 42 days, temperature inside the composted matter did not differ from the ambient temperature (Fig. 2). The composted materials amended with coffee grounds had significantly different temperature changes during the process that these amended with sewage sludge (Fig. 2). Mixtures with coffee grounds much slower entered the phase of intense microbiological decomposition, with the highest temperatures inside the composted material after 14 days. Only in the case of biomass with effluent $(\mathrm{M}+\mathrm{CG}+\mathrm{E})$, an average temperature of over $50^{\circ} \mathrm{C}$ was reached. The microbiological processes in treatments with coffee grounds were much longer, as evidenced by temperatures of the composted materials. Temperatures measured in treatments amended with coffee grounds were similar to the ambient temperature only after 98 days of the process. Although the temperature in $\mathrm{M}+\mathrm{CG}+\mathrm{E}$ treatment was higher at the beginning, after 50 days of the process, it was lower than in $\mathrm{M}+\mathrm{CG}$ and $\mathrm{M}+\mathrm{CG}+\mathrm{BC}$ treatments. However, the effect of biochar added to the composted material with sewage sludge or coffee grounds on the temperature inside the composted matter was not clear. 
Fig. 2 Average 2-week ambient temperatures and temperatures of the composted matter

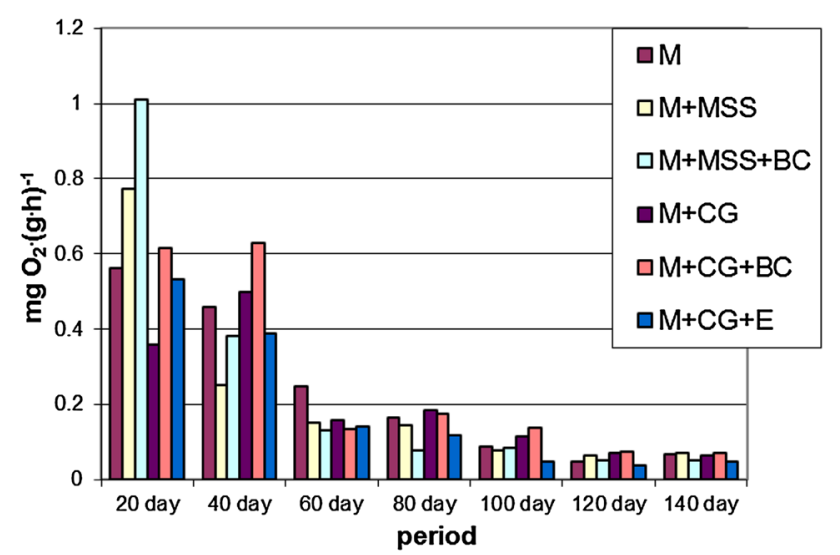

Fig. 3 The oxygen demand of compost in seven terms of the process

\section{Biological Activity}

The greatest differences in the biological activity of composts were observed on the 20th and 40th day of the process (Fig. 3). At this time, biological activity was directly linked to the process temperature (Fig. 2). Very high biological activity, measured by oxygen, demand was noted for composts amended with sewage sludge, but only on the 20th day of composting. In the case of coffee ground compost, its higher temperature after the 40th day of the process has not significantly affected the biological activity measured by oxygen demand.

One of the tests to determine the biological activity is also measurement of the seed germination energy. It was assumed that oxygen demand is lower during germination inhibition. A time of directly proportional oxygen demand was selected, which occurred after $36 \mathrm{~h}$ of the experiment
Table 2 Regression equations $(y=a+b x)$ of oxygen consumption during $37-72 \mathrm{~h}$ of spring wheat germination $(\mathrm{n}=72)$

\begin{tabular}{llll}
\hline Treatment & $\mathrm{mg} \mathrm{O}_{2}\left(\mathrm{~g} \mathrm{~h}^{-1}\right)$ & $\mathrm{R}^{2}$ & $\mathrm{~b} / \mathrm{bmax}^{\mathrm{a}}$ \\
\hline Control- $\mathrm{H}_{2} \mathrm{O}$ & $\mathrm{y}=0.2006+0.1365 \mathrm{x}$ & 0.9993 & 1.000 \\
$\mathrm{M}$ & $\mathrm{y}=0.2134+0.0966 \mathrm{x}$ & 0.9998 & 0.708 \\
$\mathrm{M}+\mathrm{MSS}$ & $\mathrm{y}=0.1808+0.1160 \mathrm{x}$ & 0.9995 & 0.849 \\
$\mathrm{M}+\mathrm{MSS}+\mathrm{BC}$ & $\mathrm{y}=0.1430+0.1311 \mathrm{x}$ & 0.9995 & 0.960 \\
$\mathrm{M}+\mathrm{CG}$ & $\mathrm{y}=0.2637+0.1236 \mathrm{x}$ & 0.9991 & 0.906 \\
$\mathrm{M}+\mathrm{CG}+\mathrm{BC}$ & $\mathrm{y}=0.1682+0.1325 \mathrm{x}$ & 0.9992 & 0.971 \\
$\mathrm{M}+\mathrm{CG}+\mathrm{E}$ & $\mathrm{y}=0.2271+0.1107 \mathrm{x}$ & 0.9993 & 0.811 \\
\hline
\end{tabular}

$M$ control - maize straw, $M+M S S$ maize straw + municipal sewage sludge, $M+M S S+B C$ maize straw + municipal sewage sludge + willow biochar, $M+C G$ maize straw + coffee grounds, $M+C G+B C$ maize straw + coffee grounds + willow biochar, $M+C G+E$ maize straw + coffee grounds + yeast effluent

${ }^{\mathrm{a}} \mathrm{bmax}=0.1365$ in control treatment

(Table 2). It was confirmed by the coefficient of determination (R2). Parameters of equation $y=a+b x$, where $y$ is oxygen consumption per $1 \mathrm{~g}$ of dry matter of seeds, indicated variations in the effect of compost extracts on the germination of wheat. The equation constant $a$ indicated minor differences between the combinations as for biological materials $(V=20.1 \%)$. Accepting the highest value of the coefficient $b$ in the control treatment with distilled water (bmax $=0.1365 \mathrm{mg} \mathrm{O}_{2} \mathrm{~g} \mathrm{~h}^{-1}$ ) as reference point, a quotient of the coefficient $b$ of individual equations and value in the control treatment [b/bmax] was calculated. Values of the quotient indicate an inhibitory effect of extracts on the seed germination capacity. Compared to the control, reduced oxygen consumption was determined for wheat seeds in contact with compost extracts. The highest growth 
inhibition of spring wheat seeds was found for maize straw compost $(\mathrm{M})$ and compost with coffee grounds and yeast effluent $(M+C G+E)$ (Table 2). Kim et al. [12] reported that aromatic compounds with aryl rings of lipophilic groups, which are present in coffee grounds, are plant growth-limiting components. They can form a film on the roots distorting the respiration processes and absorption of nutrients. Compared to the control treatment, the lowest inhibitory effect of extracts on germination energy was observed in extracts obtained from composts with the addition of biochar $(\mathrm{M}+\mathrm{MSS}+\mathrm{BC}, \mathrm{M}+\mathrm{CG}+\mathrm{BC})$.

\section{Microbiological Characteristics of Composts}

Composts with sewage sludge were characterised by a high abundance of E. coli and Salmonella ssp. (Table 3). The addition of biochar $(\mathrm{M}+\mathrm{MSS}+\mathrm{BC})$ promoted the conditions for reducing the share of the above microorganisms, but also contributed to an increase of the total number of bacteria and fungi. Composts obtained on the basis of coffee grounds were significantly less colonised by microorganisms (Table 3). In the case of composts with coffee grounds, the addition of biochar had an opposite effect to that observed for composts with sewage sludge, further reducing the number of bacteria and fungi. No desired effect of hygienisation of composts based on sewage sludge $(\mathrm{M}+\mathrm{MSS}$ and $\mathrm{M}+\mathrm{MSS}+\mathrm{BC})$ was achieved under experimental conditions, despite the thermophilic phase with a period temperature of over $50^{\circ} \mathrm{C}$. Such hygienisation is possible under industrial conditions in which higher temperatures are achieved due to less heat loss [20, 21]. However, attention should be drawn to the reduced number of E. coli and Salmonella in the treatment amended with biochar. This is probably due to more favourable air relations caused by biochar in the composted mass [22]. Kłapeć and Cholewa [23] stated that Salmonella bacteria are common in raw sludge. The authors noted that for over a decade, eggs of intestinal parasites have been reported very rarely in sewage sludge for fertiliser production, which results from the use of polyelectrolytes in the sewage treatment process. However, it is believed that health risks associated with the use of composts and organic fertilisers is real and these materials should be under microbiological and parasitological control. Furthermore, temperature in not the only factor to inactivate pathogens during the composting process [24]. Biotic interactions are also important here. It was found that the environmental use of the material located in the bottom layer of the composted biomass constitutes a microbiological hazard to it, since no full hygienisation of the material in this layer was obtained in the autumn cycle.

\section{Ecotoxicity of Composts}

Table 4 shows toxicity of the studied composts to test organisms. The inhibition of Vibrio fischeri luminescence ranged from 2 to $47 \%$, inhibition of root growth of Sinapis alba was from 1 to $60 \%$, and from 6 to $57 \%$ for Triticum L., while Eisenia fetida mortality was from 5 to $50 \%$. Despite the large variations in the response of organisms, similar relations were noticed for the toxicity of the studied composts. The lowest toxicity to all test organisms was determined for $\mathrm{M}+\mathrm{MSS}+\mathrm{BC}$ compost. The highest toxicity to $V$. fischeri was found for $\mathrm{M}+\mathrm{CG}$ compost, while $\mathrm{M}+\mathrm{CG}+\mathrm{E}$ compost was the most toxic to $\mathrm{S}$. alba, Triticum $\mathrm{L}$ and E. fetida. As in the previously presented results, significant toxicity of $\mathrm{M}$ compost was observed. The study revealed that composts with the addition of coffee grounds and biochar were less toxic to plants than to $V$. fischeri and E. fetida. In general, $\mathrm{M}+\mathrm{MSS}+\mathrm{BC}, \mathrm{M}+\mathrm{CG}$ and $\mathrm{M}+\mathrm{CG}+\mathrm{BC}$ composts were classified as non-toxic to plants. At this point, it is worth noting that samples in which the toxic effect percentage (PE\%) of up to $20 \%$ is observed are considered non-toxic, 21 to $50 \%$-low-toxic, and when PE exceeds 50\%, they are considered toxic [3, 25-27]. Therefore, toxicity of composts to specific organisms can be listed in the following order (Table 4):

Table 3 Number of tested microorganisms in dry matter of the composted material (CFU g ${ }^{-1}$ dry matter)

\begin{tabular}{|c|c|c|c|c|c|}
\hline \multirow[t]{2}{*}{ Treatment } & \multicolumn{2}{|l|}{ Total number } & \multicolumn{3}{|l|}{ Abundance } \\
\hline & Bacteria & Fungi & Coliforms & E. coli & Salmonella ssp. \\
\hline M & $183.0 \times 10^{-6} \pm 11.4 \times 10^{-6}$ & $361.4 \times 10^{-3} \pm 92.3 \times 10^{-3}$ & $151 \pm 22$ & $<3$ & $<3$ \\
\hline$M+M S S$ & $132.9 \times 10^{-6} \pm 10.9 \times 10^{-6}$ & $453.9 \times 10^{-3} \pm 151.1 \times 10^{-3}$ & $5837 \pm 1300$ & $2870 \pm 815$ & $251 \pm 119$ \\
\hline $\mathrm{M}+\mathrm{MSS}+\mathrm{BC}$ & $176.9 \times 10^{-6} \pm 24.1 \times 10^{-6}$ & $819.1 \times 10^{-3} \pm 127.7 \times 10^{-3}$ & $3113 \pm 429$ & $1179 \pm 242$ & $128 \pm 52$ \\
\hline $\mathrm{M}+\mathrm{CG}$ & $102.3 \times 10^{-6} \pm 45.2 \times 10^{-6}$ & $396.0 \times 10^{-3} \pm 83.2 \times 10^{-3}$ & $165 \pm 47$ & $<3$ & $<3$ \\
\hline $\mathrm{M}+\mathrm{CG}+\mathrm{BC}$ & $40.5 \times 10^{-6} \pm 9.8 \times 10^{-6}$ & $168.9 \times 10^{-3} \pm 32.2 \times 10^{-3}$ & $203 \pm 58$ & $34 \pm 15$ & 7 \\
\hline $\mathrm{M}+\mathrm{CG}+\mathrm{E}$ & $33.2 \times 10^{-6} \pm 4.1 \times 10^{-6}$ & $480.2 \times 10^{-3} \pm 78.8 \times 10^{-3}$ & $37 \pm 16$ & $<3$ & $<3$ \\
\hline
\end{tabular}

$M$ control-maize straw; $M+M S S$ maize straw + municipal sewage sludge, $M+M S S+B C$ maize straw + municipal sewage sludge + willow biochar, $M+C G$ maize straw + coffee grounds, $M+C G+B C$ maize straw + coffee grounds + willow biochar, $\mathrm{M}+\mathrm{CG}+\mathrm{E}$ maize straw + coffee grounds + yeast effluent 
Table 4 Toxicity of compost to test organisms

\begin{tabular}{llllll}
\hline Treatment & $\begin{array}{l}\text { Vibrio fischeri } \\
\text { IL (\%) }\end{array}$ & $\begin{array}{l}\text { Sinapis alba } \\
\text { IR }(\%)\end{array}$ & Triticum L. & $\begin{array}{l}\text { Eisenia fetida } \\
\text { M (\%) }\end{array}$ & $\begin{array}{l}\text { Class of } \\
\text { toxicity }\end{array}$ \\
\hline M & $47 \pm 12$ & $44 \pm 4$ & $49 \pm 5$ & $30 \pm 7$ & II \\
M+MSS & $22 \pm 8$ & $37 \pm 3$ & $19 \pm 10$ & $15 \pm 7$ & II \\
M+MSS + BC & $2 \pm 10$ & $5 \pm 1$ & $6 \pm 14$ & $5 \pm 7$ & I \\
M+CG & $68 \pm 11$ & $19 \pm 3$ & $16 \pm 8$ & $30 \pm 0$ & III \\
M+CG + BC & $28 \pm 17$ & $8 \pm 18$ & $19 \pm 11$ & $25 \pm 0$ & II \\
M+CG +E & $30 \pm 9$ & $60 \pm 5$ & $57 \pm 7$ & $50 \pm 0$ & III \\
\hline
\end{tabular}

$I L$ inhibition of luminescence, $I R$ inhibition of root growth for the plant, $M$ mortality rate
- V. fischeri: $\mathrm{M}+\mathrm{CG}>\mathrm{M}>\mathrm{M}+\mathrm{CG}+\mathrm{E}>\mathrm{M}+\mathrm{CG}+\mathrm{BC}$ $>\mathrm{M}+\mathrm{MSS}>\mathrm{M}+\mathrm{MSS}+\mathrm{BC}$,

- S. alba: $\mathrm{M}+\mathrm{CG}+\mathrm{E}>\mathrm{M}>\mathrm{M}+\mathrm{MSS}>\mathrm{M}+\mathrm{CG}>\mathrm{M}+\mathrm{C}$ $\mathrm{G}+\mathrm{BC}>\mathrm{M}+\mathrm{MSS}+\mathrm{BC}$,

- Triticum $\mathrm{L}: \mathrm{M}+\mathrm{CG}+\mathrm{E}>\mathrm{M}>\mathrm{M}+\mathrm{MSS}, \mathrm{M}+\mathrm{CG}+\mathrm{BC}$ $>\mathrm{M}+\mathrm{CG}>\mathrm{M}+\mathrm{MSS}+\mathrm{BC}$,

- E. fetida: $\mathrm{M}+\mathrm{CG}+\mathrm{E}>\mathrm{M}, \mathrm{M}+\mathrm{CG}>\mathrm{M}+\mathrm{CG}+\mathrm{BC}>$ $\mathrm{M}+\mathrm{MSS}>\mathrm{M}+\mathrm{MSS}+\mathrm{BC}$.

Figure 4 shows test organisms' sensitivity to toxic agent. A similar response of test organisms to modifications of composts was detected in the course of assessing their sensitivity. $V$. fischeri demonstrated the highest sensitivity, and E. fetida, the lowest (Fig. 4). Among the test plants, S. alba was slightly more sensitive than Triticum L. The greatest number of test responses of $V$. fischeri was noted for $\mathrm{M}, \mathrm{M}+\mathrm{CG}$ and $\mathrm{M}+\mathrm{CG}+\mathrm{BC}$; S. alba for $\mathrm{M}+\mathrm{MSS}$ and $\mathrm{M}+\mathrm{CG}+\mathrm{E}$; Triticum L. for M and M+MSS + BC (Fig. 4).

Evaluation of results from a set of biotests was based on the hazard classification system [25, 26]. Maize straw compost with sewage sludge and biochar $(\mathrm{M}+\mathrm{MSS}+\mathrm{BC})$ was classified to toxicity class I (non-toxic compost, no acute risk). Composts: $\mathrm{M}, \mathrm{M}+\mathrm{MSS}$ and $\mathrm{M}+\mathrm{CG}+\mathrm{BC}$ were classified to toxicity class II (non-toxic composts, low acute risk). Composts: $\mathrm{M}+\mathrm{M}+\mathrm{CG}$ and $\mathrm{M}+\mathrm{CG}+\mathrm{E}$ were classified to toxicity class III (toxic composts, acute risk). The overall toxicity of composts can be listed in the following order: $\mathrm{M}+\mathrm{CG}+\mathrm{E}>\mathrm{M}+\mathrm{CG}>\mathrm{M}>\mathrm{M}+\mathrm{MMS}>\mathrm{M}+\mathrm{CG}+$ $\mathrm{BC}>\mathrm{M}+\mathrm{MSS}+\mathrm{BC}$.

Many authors found that coffee grounds are used for energy and agriculture [9, 28]. Coffee grounds have the potential to improve soil fertility and enhance long term plant growth. Scientists are also interested in biochar, as it is a material that improves soil properties [29]. Biochar may increase the content of soil organic matter, and particularly, of extractable organic carbon. It may increase the biomass of soil microorganisms and stimulate their enzymatic activity [3, 27]. On the other hand, some scientists draw attention to the possibility of the occurrence of a negative effect of the plant growth and soil properties to the coffee grounds and biochar application to soil [28, 30]. Coffee grounds contain tannins and chlorogenic acid and might impose some toxicity in soil microorganisms and plants. Another adverse effect of coffee grounds is the reduction on mineral nitrogen content in soil [28] Heavy metals and organic contaminations occurring in biochar may be a factor limiting the use of biochar from, for example, sewage sludge $[31,32]$. An alternative to reduce the potential negative effects could be trough coffee grounds and biochar composting $[33,34]$.

To sum up, the compost from coffee grounds and biochars should be assessed. For the assessment of compost toxicity in the environment, the biological tests can be used as a useful, sensitive and quick tool. Moreover, using
Fig. 4 The number of response described for each applied biotest as the percentage from the total tests

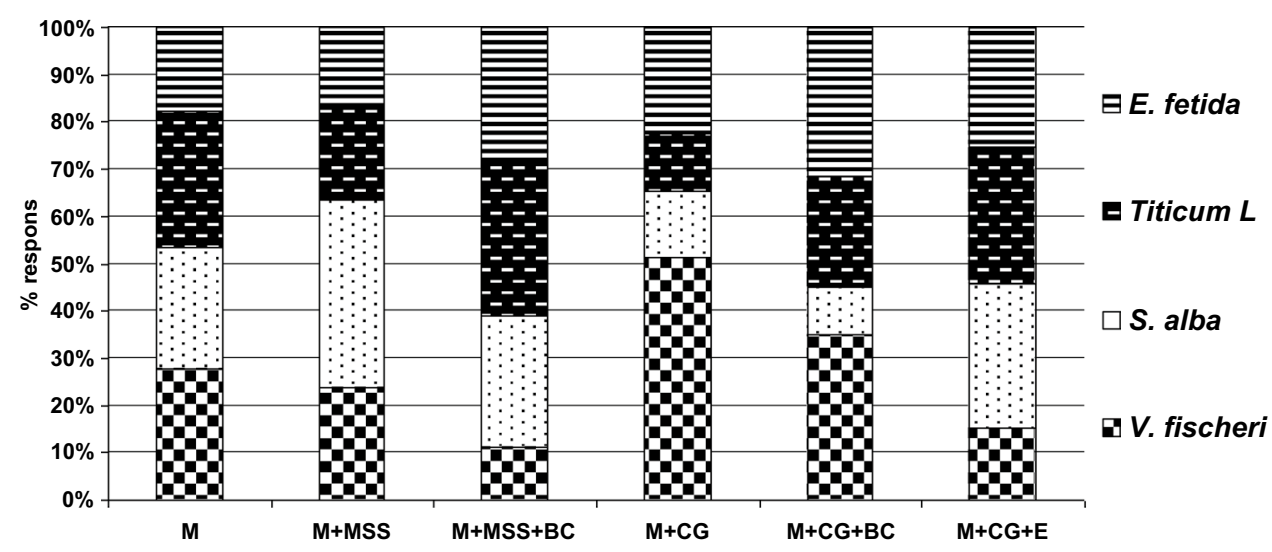


biotests working on living organisms it will be possible to evaluate the ecological risk connected with the application of these materials for fertilizing purposes.

\section{Conclusions}

1. Small (10\%) addition of biochar had no significant effect on the rate of maize straw composting measured by temperature; however, biochar-amended treatments showed a smaller loss of dry matter and higher C:N ratio.

2. The addition of coffee grounds in the composting process reduced the biological activity, but extended its duration.

3. Reduced biological activity measured by the germination capacity of seeds was identified in treatments with maize straw composts $(\mathrm{M})$ and composts enriched with coffee grounds and yeast effluent $(M+C G+E)$. The inhibitory effect on the germination capacity was alleviated in treatments amended with biochar $(\mathrm{M}+\mathrm{MSS}+\mathrm{BC}, \mathrm{M}+\mathrm{CG}+\mathrm{BC})$.

4. The addition of biochar to compost with sewage sludge $(\mathrm{M}+\mathrm{MSS}+\mathrm{BC})$ decreased the abundance of indicative microorganisms E. coli and Salmonella ssp. and increased the total number of bacteria and fungi. In the case of composts with coffee grounds, biochar had an opposite effect to that observed for composts with sewage sludge.

5. Biochar reduced the toxicity of composts. Compost toxicity was listed in the following order: $\mathrm{M}+\mathrm{CG}+\mathrm{E}$ $>\mathrm{M}+\mathrm{CG}>\mathrm{M}>\mathrm{M}+\mathrm{MMS}>\mathrm{M}+\mathrm{CG}+\mathrm{BC}>\mathrm{M}+\mathrm{MS}$ $\mathrm{S}+\mathrm{B}$.

Acknowledgements The Research was financed by the Ministry of Science and Higher Education of the Republic of Poland.

Open Access This article is distributed under the terms of the Creative Commons Attribution 4.0 International License (http:// creativecommons.org/licenses/by/4.0/), which permits unrestricted use, distribution, and reproduction in any medium, provided you give appropriate credit to the original author(s) and the source, provide a link to the Creative Commons license, and indicate if changes were made.

\section{References}

1. Holes, A., Szegi, T., Fuchs, M., Gulyás, M., Aleksza, L.: Effects of different biochars, compost and lime treatments on the chemical properties of sandy soils. Columella 1(2), 49-55 (2014)

2. Głąb, T., Palmowska, J., Zaleski, T., Gondek, K.: Effect of biochar application on soil hydrological properties and physical quality of sandy soil. Geoderma. 281, 11-20 (2016)
3. Mierzwa-Hersztek, M., Gondek, K., Baran, A.: Effect of poultry litter biochar on soil enzymatic activity, ecotoxicity and plant growth. Appl. Soil Ecol. 105, 144-150 (2016)

4. Jindo, K., Sonoki, T., Matsumoto, K., Canellas, L., Roig, A., Sanchez-Monedero, M.A.: Influence of biochar addition on the humic substances of composting manures. Waste Manag. 49, $545-552$ (2016)

5. Jindo, K., Suto, K., Matsumoto, K., Garcia, C., Sonoki, T., Sanchez-Monedero, M.A.: Chemical and biochemical characterisation of biochar-blended composts prepared from poultry manure. Biores. Technol. 110, 396-404 (2012)

6. Khan, N., Clark, I., Sánchez-Monedero, M.A., Shea, S., Meier, S., Qi, F., Kookana, R.S., Bolan, N.: Physical and chemical properties of biochars co-composted with biowastes and incubated with a chicken litter compost. Chemosphere. 142, 14-23 (2016)

7. Steiner, C., Melear, N., Harris, K., Das, K.C.: Biochar as bulking agent for poultry litter composting. Carbon Manag. 2(3), 227-230 (2011)

8. Blackwell, P., Riethmuller, G., Collins, M.: Biochar application to soil. In: Lehmann, J., Joseph, S.. (eds.) Biochar for Environmental Management: Science and Technology, pp. 207-226. Earthscan, London (2009)

9. Mussatto, S.I., Ercília, M.S., Machado E.M.S., Martins, S., Teixeira, J.A.: Production, composition, and application of coffee and its industrial residues. Food Bioprocess Tech. 4, 661-672 (2011)

10. Tsai, W.T., Liu, S.C., Hsieh, C.H.: Preparation and fuel properties of biochars from the pyrolysis of exhausted coffee residue. J. Anal. Appl. Pyrolysis. 93, 63-67 (2012)

11. Kondamudi, N., Mohapatra, S., Misra, M.: Spent coffee grounds as a versatile source of green energy. J. Agric. Food Chem. 56, 11757-11760 (2008)

12. Kim, M.S., Koo, N., Kim, J.G.: Characteristics and recycling of spent coffee grounds. Life Sci. Nat. Res. 20, 59-69 (2012)

13. Lim, T.J., Spokas, K.A., Feyereisen, G., Novak, J.M.: Predicting the impact of biochar additions on soil hydraulic properties. Chemosphere. 142, 136-144 (2016)

14. ISO 14855-1 2005: Determination of the ultimate aerobic biodegradability of plastic materials under controlled composting conditions - method by analysis of evolved carbon dioxide-Part 1: general method

15. OxiTop ${ }^{\circledR}$ Measuring System: Wageningen University and NMI, p. 13 (2003)

16. Pepper, I.L., Gerba, C.G.: Environmental Microbiology. A laboratory manual, 2nd edn, p. 209. Elsevier AP, Amsterdam, (2005)

17. MicrobicsCorporation: Microtox manual toxicity testing handbook. MicrobicsCorporation, Carlsbad, (1992)

18. Phytotoxkit ${ }^{\mathrm{TM}}$ : Seed germination and early growth microbiotest with higher plants. Standard Operational Procedure. Nazareth, p. 24. MicroBioTest Inc, Belgium (2004)

19. Akhter, A., Hage-Ahmed, K., Soja, G., Steinkellner, S.: Compost and biochar alter mycorrhization, tomato root exudation, and development of Fusarium oxysporum f. sp. lycopersici. Front. Plant Sci. 6, 529 (2015)

20. Wolna-Maruwka, A., Czekała, J., Piotrowska-Cyplik, A.: Estimation of the inactivation rate of pathogenic bacteria in sewage sludge given the composting process in cybernetic bioreactor. J. Res. Appl. Agric. Eng. 54(1), 73-79 (2009)

21. Kosicka-Dziechciarek, D., Wolna-Murawka, A., Mazurkiewicz, J.: The danger of pathogenic organisms in sewage sludge and methods of their reduction. Arch. Waste Manag. Environ. Prot. 17(4), 127-138 (2015)

22. Kopeć, M., Gondek, K., Mierzwa-Hersztek, M., Zaleski, T.: Effect of the composting process on physical and energetic changes in compost. Acta Agrophys. 23(4), 607-619 (2016) 
23. Kłapeć, T., Cholewa, A.: Health risk associated with the use of organic and organic-mineral fertilizers. Gen. Med. Health Sci. 18(2), 131-136 (2012) (in polish)

24. Szala, B., Breza-Boruta, B.: Survival of faecal indicators in the process of sewage sludge composting. Zeszyty Prob. Post. Nauk Rol. 580, 131-139 (2015) (in polish)

25. Persoone, G., Marsalek, B., Blinova, I., Törökne, A., Zarina, D., Manusadzianas, L., Nalecz-Jawecki, G., Tofan, L., Stepanova, N., Tothova, L., Kolar, B.: A practical and user-friendly toxicity classification system with microbiotests for natural waters and wastewaters. Environ. Toxicol. 18(6), 395-402 (2003)

26. Kopeć, M., Gondek, K., Baran, A.: Assessment of respiration activity and ecotoxicity of composts containing biopolymers. Ecotox. Environ. Saf. 89, 137-142 (2013)

27. Gondek, K., Mierzwa-Hersztek, M., Baran, A., Szostek, M., Pieniążek, R., Pieniążek, M., Stanek-Tarkowska, J., Noga, T.: The effect of low-temperature conversion of plant materials on the chemical composition and ecotoxicity of biochars. Waste Biomass Valor. (2016). doi:10.1007/s12649-016-9621-2

28. Yamane, K., Kono, M., Fukunaga, T., Iwai, K., Sekine, R., Watanabe, Y., Iijima, M.: Field evaluation of coffee grounds Application for crop growth enhancement, weed control and soil improvement. Plant Prod. Sci. 17(1), 93-102 (2014)
29. Arthur, E., Tuller, M., Moldrup, P., de Jonge, L.W.: Effects of biochar and manure amendments on water vapor sorption in a sandy loam soil. Geoderma. 243-244, 175-182 (2015)

30. Spokas, K.A., Novak, J.M., Stewart, C.E., Cantrell, K.B., Uchimiya, M., DuSaire, M.G., Ro, K.S.: Qualitative analysis of volatile organic compounds on biochar. Chemosphere. 85(5), 869-882 (2011)

31. Gondek, K., Baran, A., Kopeć, M.: The effect of low-temperature transformation of mixtures of sewage sludge and plant materials on content, leachability and toxicity of heavy metals. Chemosphere. 117, 33-39 (2014)

32. Meier, S., Curaqueo, G., Khan, N., Bolan, N., Rilling, J., Vidal, C., Fernández, N., Acuna, J., González, M.E., Cornejo, P., Borie, F.: Effect of biochar on copper immobilization and soil microbial communities in a metal-contaminated soil. J. Soils Sediments (2015). doi:10.1007/s11368-015-1224-1

33. Batish, D.R., Singh, H.P., Kaur, M., Kohli, R.K., Yadav, S.S.: Caffeine affects adventitious rooting and causes biochemical changes in the hypocotyls cuttings of mung bean (Phaseolus aureus Roxb.). Acta Physiol. Plant. 30, 401-405 (2008)

34. Cruz, R., Baptista, P., Cunha, S., Pereira, J. A., Casal, S.: Carotenoids of lettuce (Lactuca sativa $\mathrm{L}$.) grown on soil enriched with spent coffee grounds. Molecules. 17, 1535-1547 (2012) 